\title{
COVID-19 Pandemic: Other Perspective. Saudi Arabia
}

Osama A. Zitoun.'

\section{The Experience}

As of April 2020, the novel COVID-19 Pandemic has permeated nearly our entire world. In response to the unreasonable number of deaths and infected people, many governments have taken actions in an aim to limit the spread. In the Kingdom of Saudi Arabia, the suspension of schools and universities took place on the $8^{\text {th }}$ of March, and all academic activities were to be carried out through online education. Shut-down of all social gatherings and special events and announcements of lockdown and curfews have followed. ${ }^{2}$ Indeed, for a senior student in the final year at medical school, this was rather frustrating. My college was beginning in the preparation of graduation ceremony before the winds of COVID-19 degraded all arrangements.

\section{Fear and Social Media.}

Overwhelming news captions added fear and anxiety to the preexisting situation as well as promoted rumors and overemphasized information that unqualified individuals provided. ${ }^{3}$ Many resources and newspapers refer to the COVID-19 as to be caused by a Chinese Virus, influencing the public to target the Chinese People blame them for spreading the disease. ${ }^{4}$ Moreover, deceptive rumors and conspiracy hypotheses about the emergence of the COVID-19 have spread around the globe through social media channels to cause what can be called as: (Pandemic of Social Media Panic). 5

\section{The Ethical Dilemma.}

Few emerging infectious diseases have constituted many ethical challenges as dramatic as the novel COVID-19. The shortage of healthrelated resources will certainly affect patients other than COVID-19 patients, such as heart disease, diabetes, and cancer patients. ${ }^{6}$ Disarrangement of the health care system may cause more deaths of patients with a diversity of critical health needs other than that of COVID-19 patients. Thus, in a crisis, we have to adjust the standard of care to highlight the demands of the community and still provide the best achievable individual-level health care. ${ }^{7}$ If vulnerable and poor individuals of a community are not capable of practicing physical distancing or accessing health care services, then all members of that community will be at substantial risk. ${ }^{8}$

\section{Other Perspective.}

Well, if I want to have a pure pessimistic view of our current situation, this brief experience account will not be adequate to discuss all negative aspects. Nevertheless, our current isolation and quarantine are not disadvantageous all the way. The main question that I was thinking about recently was: What if this pandemic with the same statistics was to happen at the beginning of the 21st Century? I believe that nearly all educational activities and work will be halted. Most aspects that can be substituted by digital tools and replacements will be simply discontinued. In our current case, thanks to the new technologies, we are nearly on track by actively engaging in our education and even social communication. We are now having much free time, which many of us have formerly longed for. We can now take the online courses which we have ever since procrastinated. We could make use of this time to finish pending projects, learn new skills, or just get together with our families. Of course, during quarantine, we may expect a decrease in productivity, state of distraction, low motivation, and difficulty in maintaining concentration. 9 We can try to manage these inconveniences' threshold by prioritizing sleep, eating well, exercising, and most importantly being optimistic.

\section{Conclusion.}

Public health education about COVID-19 and its prevention should be intensified to soothe panic and assemble the general population to cooperatively withstand the pandemic. ${ }^{10}$ While the COVID- 19 is now a global public health issue, stigma and discrimination should not be neglected as their effects may pull-down the worldwide efforts to control this pandemic. Finally, as the valid measures at hand to oppose COVID-19 are nonpharmaceutical interference procedures such as physical distancing and quarantine, social media should be used to promote the public to follow these measures and maintain the spread of uncertainty and fear.

1 Medical student, Sulaiman Alrajhi University, Saudi Arabia. 


\section{References}

1. REUTERS. Saudi Arabia suspends schools, universities over coronavirus fears. 2020. Available from: https://www.reuters.com/article/us-health-coronavirussaudi/saudi-arabia-suspends-schools-universities-over-coronavirus-fearsidUSKBN20VoYO. Cited Mar 8, 2020

2. Business A. Saudi Arabia imposes 24 -hour virus curfew in five cities. 2020

3. Shigemura J, Ursano RJ, Morganstein JC, Kurosawa M, Benedek DM. Public responses to the novel 2019 coronavirus (2019-nCoV) in Japan: Mental health consequences and target populations. Psychiatry Clin Neurosci. 2020 Apr;74(4):281-282.

4. Atlani-Duault L, Ward JK, Roy M, Morin C, Wilson A. Tracking online heroisation and blame in epidemics. Lancet Public Health. 2020 Mar;5(3):e137-e138.

5. Depoux A, Martin S, Karafillakis E, Bsd RP, Wilder-Smith A, Larson H. The pandemic of social media panic travels faster than the COVID-19 outbreak. J Travel Med. 2020 Mar 3. pii: taaa031.
6. Brolin Ribacke KJ, Saulnier DD, Eriksson A, von Schreeb J. Effects of the West Africa Ebola Virus Disease on Health-Care Utilization - A Systematic Review. Front Public Health. 2016 Oct 10;4:222.

7. Hanfling D, Altevogt BM, Gostin LO. A framework for catastrophic disaster response. JAMA. 2012 Aug 15;308(7):675-6.

8. Costin LO, Friedman EA, Wetter SA. Responding to COVID-19: How to Navigate a Public Health Emergency Legally and Ethically. Hastings Cent Rep. 2020 Mar;50(2):8-12

9. Dickerson D. Seven tips to manage your mental health and well-being during the COVID-19 outbreak. Nature. 2020 Mar 26.

10. Luan RS, Wang X, Sun X, Chen XS, Zhou T, Liu QH, et al. [Epidemiology, Treatment, and Epidemic Prevention and Control of the Coronavirus Disease 2019: a Review]. Sichuan Da Xue Xue Bao Yi Xue Ban. 2020 Mar;51(2):131-138. Chinese

\section{Acknowledgments}

None.

Conflict of Interest Statement at Funding

The Authors have no funding, financial relationships or conflicts of interest to disclose.

Author Contributions

Conceptualization, Writing - Original Draft and Writing - Review đ Editing: $0 Z$.

Cite as:

Zitoun OA. COVID-19 Pandemic: Other Perspective. Saudi Arabia. Int J Med Students. 2020 Jan-Apr;8(1):64-65.

This work is licensed under a Creative Commons Attribution 4.0 International License

ISSN 2076-6327

This journal is published by the University Library System, University of Pittsburgh as part of the Digital Publishing Program and is co-sponsored by the University of Pittsburgh Press. 